\title{
Sex differences in angiotensin II- induced hypertension
}
B. $\mathrm{Xue}^{2}$,
A.K. Johnson ${ }^{2,3,4,5}$ and M. Hay ${ }^{1,2,5}$

\author{
${ }^{1}$ Department of Molecular Physiology and Biophysics, \\ ${ }^{2}$ Department of Psychology, ${ }^{3}$ Department of Integrative Physiology, \\ ${ }^{4}$ Department of Pharmacology, ${ }^{5}$ Cardiovascular Center, University of lowa, \\ lowa City, IA, USA
}

\author{
Correspondence \\ M. Hay \\ Vice President for Research \\ University of lowa \\ 201 Gilmore Hall \\ lowa City, IA 52242 \\ USA \\ Fax: +1-319-335-2104 \\ E-mail: meredith-hay@uiowa.edu \\ Presented at the International \\ Symposium of Neuroendocrinology \\ "Neuroendocrine control of body \\ fluid homeostasis: past, present \\ and future". Ribeirão Preto, SP, \\ Brazil, September 1-3, 2006. \\ Research supported by the National \\ Heart, Lung, and Blood Institute \\ (HL-59676 and HL-62261 for \\ M. Hay), (HL-14388 and HL-57472) \\ and the National Institute of Diabetes \\ and Digestive and Kidney Diseases \\ (DK-66086 for A.K. Johnson).
}

..................

\begin{abstract}
Sex differences in the development of hypertension and cardiovascular disease have been described in humans and in animal models. In this paper we will review some of our studies which have as their emphasis the examination of the role of sex differences and sex steroids in modulating the central actions of angiotensin II (ANG II) via interactions with free radicals and nitric oxide, generating pathways within brain circumventricular organs and in central sympathomodulatory systems. Our studies indicate that low-dose infusions of ANG II result in hypertension in wild-type male mice but not in intact wild-type females. Furthermore, we have demonstrated that ANG IIinduced hypertension in males is blocked by central infusions of the androgen receptor antagonist, flutamide, and by central infusions of the superoxide dismutase mimetic, tempol. We have also found that, in comparison to females, males show greater levels of intracellular reactive oxygen species in circumventricular organ neurons following long-term ANG II infusions. In female mice, ovariectomy, central blockade of estrogen receptors or total knockout of estrogen $\alpha$ receptors augments the pressor effects of ANG II. Finally, in females but not in males, central blockade of nitric oxide synthase increases the pressor effects of ANG II. Taken together, these results suggest that sex differences and estrogen and testosterone play important roles in the development of ANG II-induced hypertension.
\end{abstract}

Key words

- Angiotensin II

- Estrogen

- Estrogen $\alpha$ and $\beta$ receptors

- Nitric oxide

- Reactive oxygen species

- Testosterone

\section{Introduction}

In general, men are at greater risk for cardiovascular disease and hypertension than premenopausal women of the same age $(1,2)$. Ambulatory blood pressure measurements have consistently found that men aged 50-60 years have higher blood pressures than premenopausal, age-matched women $(3,4)$. In animal models of hypertension, studies have also shown that males have higher blood pressure than females (5-7). Angiotensin II (ANG II) is an important factor in many forms of clinical and experimental hypertension. In animals, low doses of ANG II are known to induce neurogenic hypertension via the central nervous system by acting through brain circumventricular organs $(8,9)$. An increasing body of evidence has shown that the central and peripheral effects of 
ANG II involve activation of reactive oxygen $(10,11)$. Similarly, central and peripheral studies with estrogen (E2) and testosterone have shown that many of their cardiovascular-related effects may involve modulation of the generation of reactive oxygen species (ROS) and nitric oxide (NO) (1214). In many systems, cardiovascular homeostasis is maintained by the balance between the ROS and NO systems. Therefore, understanding the nature of any imbalance in NO/ROS signaling activated by ANG II and the contribution of sex differences and sex steroids to such dysfunction will be of key importance for developing new treatments for ANG II-related cardiovascular disease. The purpose of this review is to summarize recent developments that implicate a role for sex-related mechanisms modulating the central actions of ANG II and, in particular, the role of free radical- and NO-generating pathways.

\section{Sex differences in angiotensin II- induced hypertension}

Central actions of ANG II increase sympathetic nerve activity and modulate reflex

Figure 1. $A$, Telemetry measurement (TA11PA-C20, Data Sciences International, St. Paul, MN, USA) of mean arterial pressure (MAP) before and during infusion of angiotensin II (ANG II, $800 \mathrm{ng} \mathrm{kg}^{-1} \mathrm{~min}^{-1}$ ) in male and female mice. Control days are denoted by $\mathrm{C}$, followed by the 7 days of ANG II infusion. ${ }^{*} \mathrm{P}<$ 0.05 compared to baseline, ${ }^{+} \mathrm{P}<$ 0.05 compared to females (twoway ANOVA). B, Averaged increases in MAP induced by ANG II infusion in intact and gonadectomized mice. Data are reported as means \pm SEM for 6 mice in each group. ${ }^{* *} \mathrm{P}<0.05$ compared to castrated males, ${ }^{++} \mathrm{P}<0.05$ compared to ovariectomized (OVX) females (one-way ANOVA).

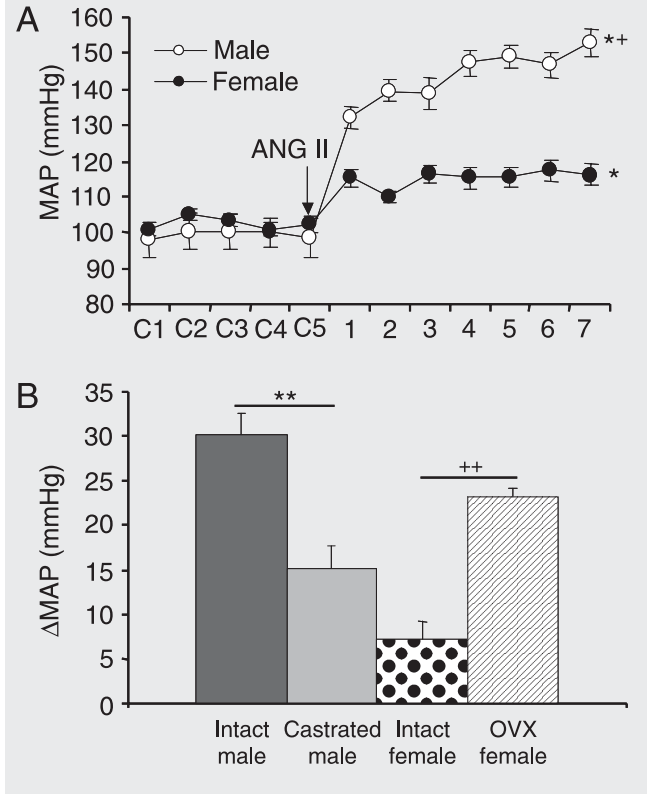

regulation of heart rate through actions of the peptide on sensory circumventricular organs (15) such as the area postrema, subfornical organ and organum vasculosum of the lamina terminalis $(8,16-20)$. It has been reported that chronic low-dose ANG II-induced hypertension, which develops over a period of days, is not due to the peripheral vasoconstrictor activity of ANG II, but is most likely the result of excitation of the sympathetic nerve activity $(8,17)$. Recent studies from our laboratory have shown in mice that decreases in blood pressure induced by ganglionic blockade are much smaller on day 1 as compared to day 7 of ANG II infusion, thus suggesting that an enhancement of sympathetic outflow contributes to the ANG II-induced progressive increase in blood pressure (21). The results obtained by Hendel and Collister (18) confirm that the chronic phase of ANG II hypertension has a significant neurogenic component and that this sympathoexcitation is mediated via the subfornical organ.

There is increasing evidence that the actions of ANG II on the central nervous system may differ between sexes. Doursout et al. (22) have reported that the blood pressure and dipsogenic responses to centrally administered ANG II in conscious dogs are substantially augmented in males relative to females. Recent studies from our laboratory have shown that 1) low-dose infusion of ANG II increases blood pressure in male but not female mice (Figure 1A), and 2) gonadectomy attenuates ANG II-induced hypertension in male mice and augments hypertension in females (Figure 1B). Furthermore, we have reported that ganglionic blockade produces greater reductions in blood pressure in males compared to females during ANG II infusion, and reflex bradycardic responses are blunted in males but not in females during chronic ANG II infusion. These results suggest that female mice are protected against the development of ANG IIinduced hypertension and that sex hormones 
play an important modulatory role in the pathogenesis of ANG II-induced hypertension. Furthermore, attenuated baroreflex sensitivity and increases in sympathetic outflow appear to contribute to the hypertension observed in the male (21).

Although the mechanisms underlying the sex differences in ANG II-induced hypertension are unknown, substantial evidence has accumulated to show that sex differences and sex hormones affect components of the renin-angiotensin system (23). For example, testosterone treatment in ovariectomized (OVX) female rats increases plasma renin activity, while plasma renin activity, plasma angiotensin-converting enzyme activity and angiotensinogen mRNA decrease after castration of males $(24,25)$. In contrast, E2 may decrease components of the renin-angiotensin system (23). E2 has been shown to reduce angiotensin type 1 $\left(\mathrm{AT}_{1}\right)$ receptor binding and $\mathrm{mRNA}$ in the subfornical organ in female rats (26); this may indicate that E2 might attenuate ANG II activation of subfornical organ neurons and the development of ANG II-induced hypertension in females.

\section{The role of sex hormones and their central receptors in angiotensin II- induced hypertension}

Physiologically relevant concentrations of E2 have both rapid and long-term positive cardiovascular effects which are mediated by two types of estrogen receptors (ER), $\mathrm{ER} \alpha$ and ERß (27). Crucial roles for ER $\alpha$ in the protection against vascular injury, activation of endothelial NO synthase (NOS) and anti-atherosclerotic effects have been amply documented $(28,29)$. Genetic deletion of ERß results in the development of hypertension in middle-aged female and male mice due to multiple abnormalities of ion channel function in blood vessels (30). However, very little is known about the role of ER in the central nervous system regarding the mediation of the cardiovascular protective effects of E2.

Saleh et al. $(31,32)$ have shown that in OVX female rats, E2 administration into several hindbrain nuclei, such as the nucleus of the solitary tract, nucleus ambiguous and parabrachial nucleus, and into the intrathecal space inhibits sympathetic efferent activity but enhances parasympathetic efferent activity. These effects of E2 were blocked by pretreatment with the ER antagonist, ICI182,780. Moreover, central injection of ICI182,780 blocked increased vagal nerve activity and decreased renal nerve activity induced by bolus injections of E2 (iv), thereby indicating that peripherally administered E2 modulates baseline autonomic tone via the activation of central ERs (33). Studies from our laboratory have shown that 17ßestradiol facilitates area postrema calciumactivated $\mathrm{K}^{+}$currents and inhibits area postrema neuronal activity (34). 17ß-estradiol also inhibits an increase in $\left(\mathrm{Ca}^{2+}\right)_{\mathrm{i}}$ induced by application of ANG II to cultured area postrema neurons (35). This evidence reinforces the importance of a central antihypertensive action of E2.

Recently, we reported that central infusion of the ER antagonist ICI182,780 facilitates ANG II-induced hypertension in females. Furthermore, we have shown that in female ER $\alpha$ knockout mice ANG II increases blood pressure in a similar manner to that seen in OVX, wild-type females (Figure 2), suggesting that E2 protects against ANG II-

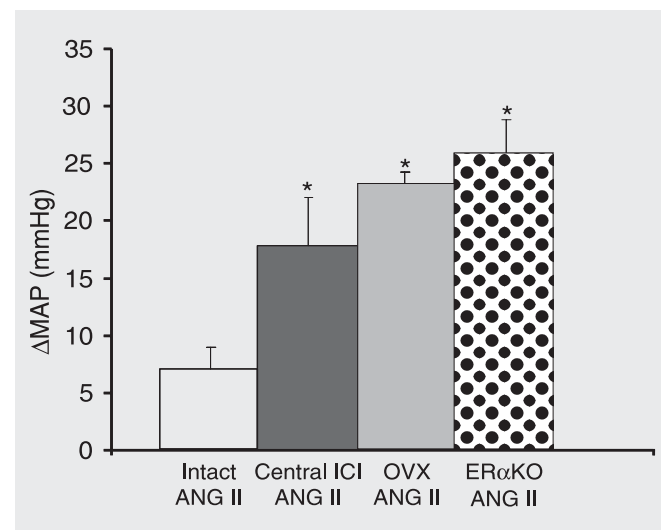

Figure 2. Comparison of increases in mean arterial pressure ( $\triangle \mathrm{MAP})$ induced by angiotensin II (ANG II, $800 \mathrm{ng} \mathrm{kg}^{-1}$ $\mathrm{min}^{-1}$ ) infusion in intact, central ICl182,780 (ICl, $1.5 \mathrm{\mu g} \mathrm{kg}^{-1}$ day $\left.^{-1}\right)$ treated, ovariectomized (OVX), and estrogen receptor alpha knockout $(E R \alpha K O)$ female mice. Data are reported as means \pm SEM for 6 mice in each group. ${ }^{*} \mathrm{P}<0.05$ compared to intact females (one-way ANOVA). 
induced hypertension in females via actions on the ER $\alpha(36,37)$.

Studies in humans and animals suggest that testosterone is a pro-hypertensive hormone (38). Studies using ambulatory blood pressure monitoring techniques in children have shown that with increasing age, blood pressure increases in both young boys and girls. However, after the onset of puberty, boys have higher blood pressure than agematched girls (39). These data show that in adolescence and puberty, when androgen levels are increasing, blood pressure is higher in males than in females. In animal models, blood pressure is higher in male spontaneously hypertensive, Dahl salt-sensitive, and deoxycorticosterone acetate-salt hypertensive rats as compared to the same hypertensive models when females are studied $(7,40$, 41). Treatment of OVX normotensive females or castrated males with testosterone increases blood pressure to levels similar to those of intact males, and testosterone increases blood pressure in OVX female spontaneously hypertensive rats. Moreover, chronic blockade of androgen receptors with the antagonist flutamide reduces blood pressure in male spontaneously hypertensive rats to the level found in female spontaneously hypertensive animals (42). Thus, increases in androgens in humans and in normotensive and hypertensive rats lead to higher blood pressure.

Figure 3. Averaged change in mean arterial pressure ( $\triangle \mathrm{MAP})$ induced by angiotensin II (ANG II, $800 \mathrm{ng} \mathrm{kg}^{-1} \mathrm{~min}^{-1}$ ) infusion in intact, castrated (Cas), and central flutamide (Flu, $0.8 \mathrm{mg} \mathrm{kg}^{-1}$ day $\left.^{-1}\right)$-treated male mice. Data are reported as means \pm SEM for 5 mice in each group. ${ }^{*} \mathrm{P}<$ 0.05 compared to intact males (one-way ANOVA).

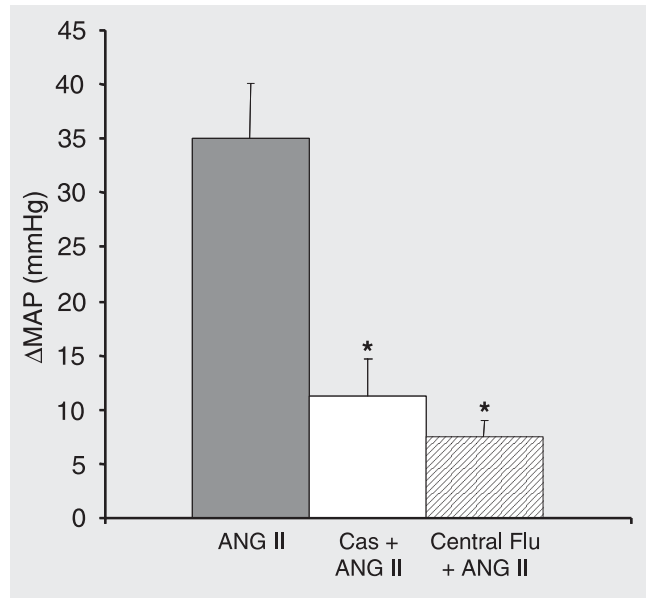

The mechanisms by which testosterone affects blood pressure are multifaceted and involve direct effects on vascular, renal and heart cells $(38,43)$. However, there are very few studies on the central effects of androgen as well as its receptor on blood pressure and cardiovascular regulation, and this is just beginning to be investigated. Data from our laboratory show that the use of intracerebroventricular flutamide infusion to block androgen receptors in the central nervous system significantly attenuates the development of ANG II-induced hypertension in male mice (Figure 3). These results indicate that central androgen receptors might mediate the hypertensive effects of sex hormones during infusions of ANG II in mice (44). The mechanisms underlying the role of male sex hormones and androgen receptors in altering ANG II activation of the central nervous system need to be studied further.

\section{Reactive oxygen species and nitric oxide in sex differences in angiotensin II-induced hypertension}

\section{Reactive oxygen species and sex differences}

Oxidative stress can be characterized by an imbalance between the generation and the scavenging of oxide radicals (e.g., $\mathrm{O}_{2}{ }^{-}$or hydrogen peroxide) and has been identified as a key component of the pathogenesis of central and peripheral diseases (45). Recent studies have shown that superoxide radicals are critical determinants of the central actions of ANG II $(11,46,47)$. These studies demonstrate that overexpression of superoxide dismutase (SOD) within the region of the subfornical organ by administration of an adenoviral vector containing the gene coding human MnSOD and CuZnSOD blocks the pressor, bradycardic and dipsogenic effects of centrally administered ANG II. Further, these investigators also found that MnSOD is co-expressed with $\mathrm{AT}_{1}$ receptors in the subfornical organ, thus sup- 
porting the hypothesis that central ANG IIinduced hypertension involves ROS activation within ANG II-sensitive circumventricular organs. Recent data from our laboratory have shown that lateral icv infusion of tempol, a SOD mimetic, blocks systemic ANG IIinduced hypertension in male mice $(48,49)$. This suggests that central ROS activation is required for $\mathrm{ANG}$ II-induced hypertension in males (Figure 4).

Testosterone and E2 have been shown to alter oxidative stress at both peripheral and central sites. In endothelial cells E2 has recently been shown to inhibit ANG II-induced increases in expression of nicotinamide adenine dinucleotide phosphate, the reduced form (NADPH) and NOS (13). In vascular smooth muscle cells, E2 decreases ANG II-induced free radical production and up-regulates MnSOD and extracellular SOD, suggesting that the cardiovascular protection of E2 against peripheral ANG II-induced oxidative stress is due to an increase in SOD activity induced by E2 (12). Using real-time measurements of reactive oxygen generation with dihydroethidium in living brain slices, our laboratory has shown that ANG II increases ROS production in subfornical organ neurons and that this effect is blocked by tempol (Figure 5A). Importantly, incubation of the slices in E2 blocks ANG IIinduced increases in ROS (Figure 5B), suggesting that E2 may inhibit central ANG II effects by inhibiting ROS production (50).

\section{Nitric oxide and sex differences}

NO synthesized from its precursor Larginine by the enzyme NOS is an important mediator of intracellular signaling in various tissues. Neuronal NOS (nNOS) activity has been demonstrated in central and peripheral autonomic nervous system sites that are involved in the control of blood pressure regulation (51). There are a large number of studies examining the central effects of NO on sympathetic outflow. For example, within

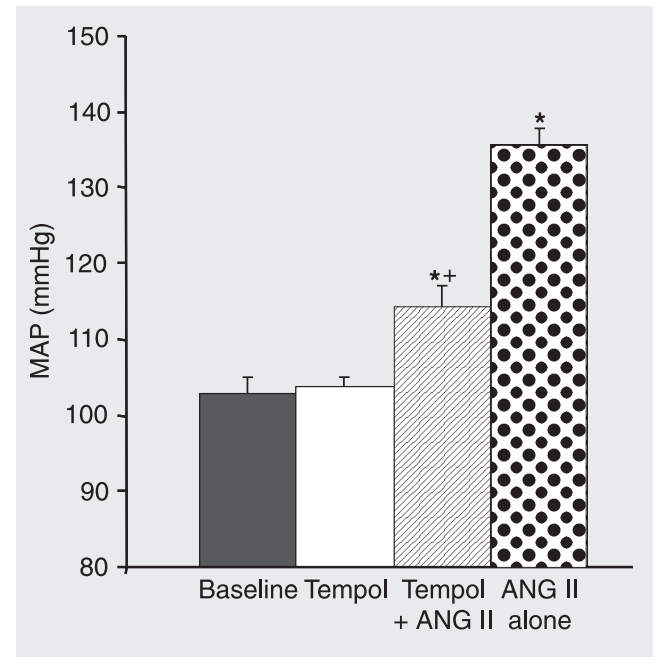

Figure 4. Mean blood pressures (MAP) during infusion of tempol (200 $\mathrm{nM} \mathrm{kg}^{-1} \mathrm{~min}^{-1}$ ) into the lateral ventricles were not significantly different from baseline blood pressure; however, central administration of tempol during subcutaneous infusion of angiotensin II (ANG II, $800 \mathrm{ng} \mathrm{kg}^{-1}$ $\mathrm{min}^{-1}$ ) attenuated the increases in blood pressure observed with infusion of ANG II alone. Data are reported as means \pm SEM for 7 mice in each group. ${ }^{*} \mathrm{P}<$ 0.05 compared to baseline; ${ }^{+} \mathrm{P}<$ 0.05 compared to ANG II alone (one-way ANOVA).

A
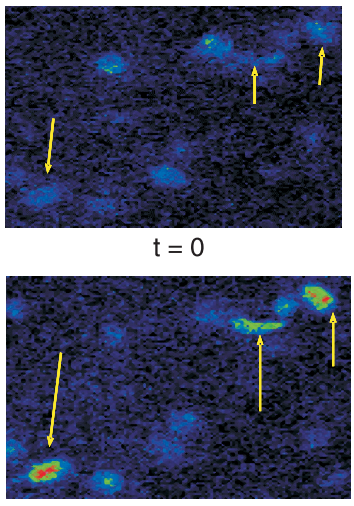

$\mathrm{t}=180 \mathrm{~s}$

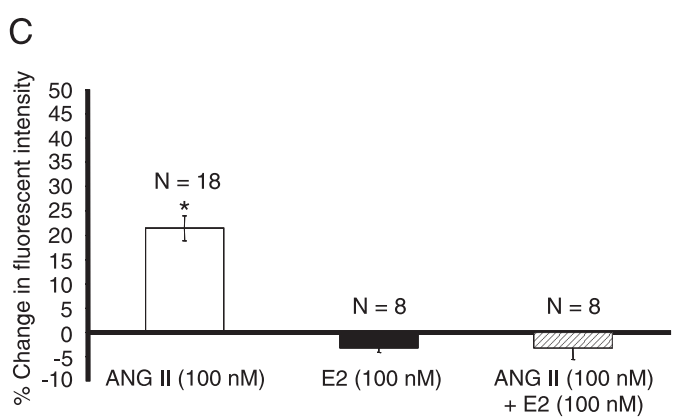

Figure 5. $A$, Pseudocolor images showing increases in ethidium fluorescence intensity in the subfornical organ during superfusion of slices with angiotensin II (ANG II). Arrows indicate cells in which intensity increased. $B$, Changes in ethidium fluorescence evoked by superfusion of ANG II (100 $\mathrm{nM})$ in the absence and presence of tempol (1 mM). ANG IIevoked increases in intracellular reactive oxygen species (ROS) in the subfornical organ brain slice are blocked by tempol. $C$, The effects of 17ß-estradiol (E2, $100 \mathrm{nM})$ on ANG II (100 nM)-induced intracellular generation of ROS. In the presence of E2, ANG II-induced percent increase of fluorescence intensity is significantly inhibited. Data are reported as means \pm SEM. ${ }^{*} \mathrm{P}<0.05$ compared to E2 alone or E2 + ANG II (one-way ANOVA). 
the hypothalamus, the largest population of NO cells is found within the paraventricular nucleus. Increases in NO within the paraventricular nucleus result in decreases of sympathetic outflow and blood pressure, and NO plays an important central role in reducing arterial pressure during recovery from psychological stress (52).

Figure 6. Mean blood pressures (MAP) during infusion of $\mathrm{N}^{\omega}$-nitro-L-arginine methyl ester (LNAME, $0.5 \mathrm{mg} \mathrm{kg}^{-1}$ day $^{-1}$ ) into the lateral ventricles were not significantly different from baseline blood pressures in female mice; however, central administration of L-NAME augmented an angiotensin II (ANG II, 800 ng $\left.\mathrm{kg}^{-1} \mathrm{~min}^{-1}\right)$-induced increase in blood pressure. Data are reported as means \pm SEM for 6 mice in each group. ${ }^{*} \mathrm{P}<0.05$ compared to baseline, ${ }^{+} \mathrm{P}<0.05$ compared to ANG II alone (oneway ANOVA).
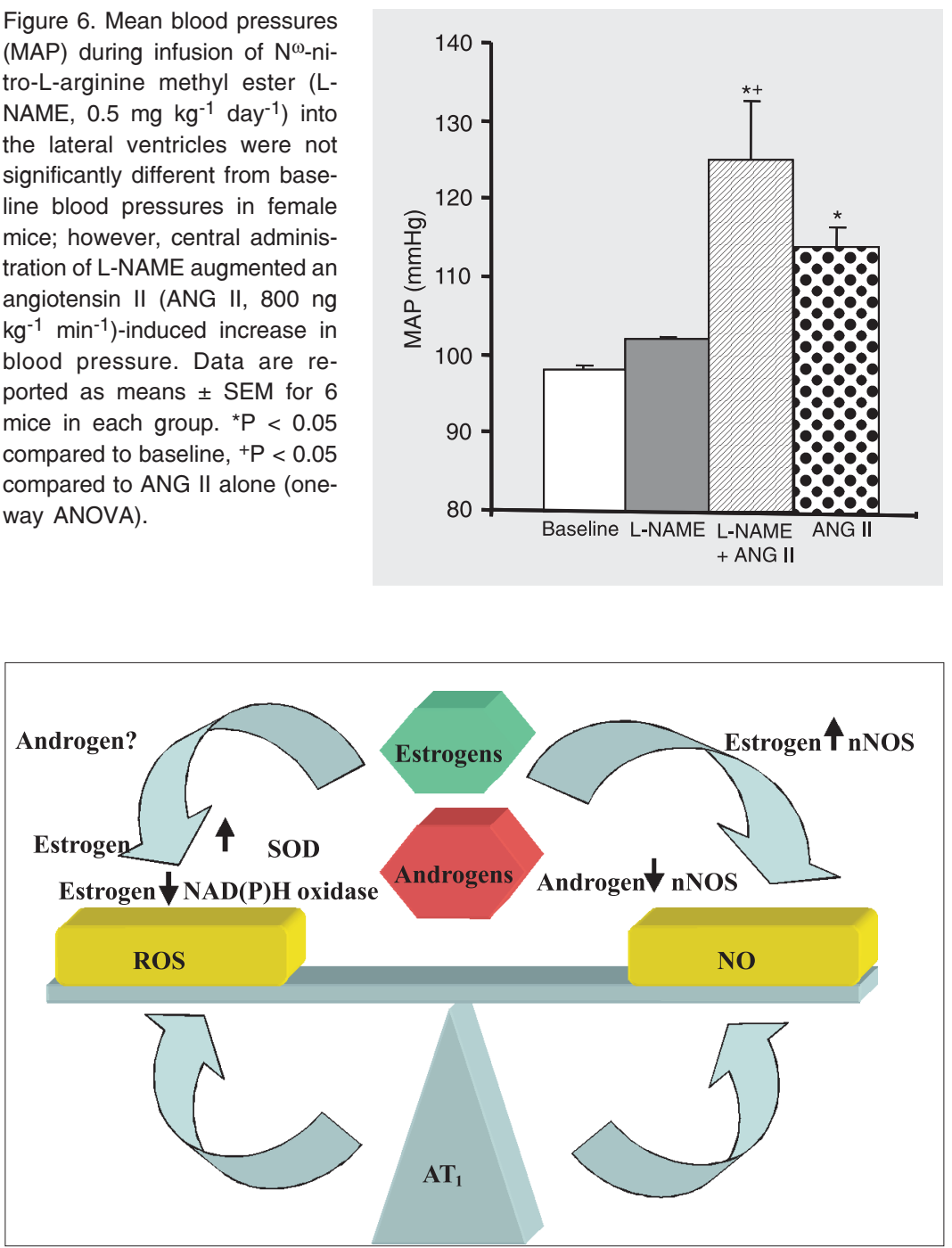

Figure 7. Schematic representations of the hypothetical mechanisms of interaction of sex hormones, angiotensin II (ANG II), nitric oxide (NO), and reactive oxygen species (ROS). Both estrogen and testosterone are assumed to have actions in the central nervous system that modulate the activity of ROS and neuronal NO synthase (nNOS) pathways, thereby modulating the hypertensive effects of central angiotensin type $1\left(A T_{1}\right)$ receptor activation by ANG II. SOD = superoxide dismutase; $N A D(P) H=$ nicotinamide adenine dinucleotide phosphate, the reduced form.
A differential modulation of nNOS expression and/or activity has been proposed to be related to observed sex differences in NO release. Recent studies demonstrate that E2 up-regulates endothelial NOS in endothelial cells (53) and nNOS in the brain (54, 55). Many of the actions of E2 on the brain have been suggested to be through an NOmediated mechanism $(54,55)$. Castration increases and androgen treatment decreases nNOS activity in the brain (56). Immunohistochemical studies from our laboratory also revealed co-localization of nNOS and ER $\alpha$ in the subfornical organ of female mice (57). Moreover, Wang et al. (58) recently reported that there are sex differences in the development of long-term $\mathrm{N}^{\omega}$-nitro-L-arginine methyl ester (L-NAME)-induced hypertension in rats. L-NAME-treated females exhibited a significantly higher elevation of blood pressure than males. Results from our laboratory have demonstrated that the increases in blood pressure induced by ANG II are significantly greater in female mice given central infusions of L-NAME than in control mice (57) (Figure 6). This raises the possibility that activation of the endogenous NO system may buffer the stimulatory effects of ANG II on central sympathetic nervous system activity, especially in females.

In many systems the harmful effects of ROS are offset by NO production (45). When these systems are out of balance, an increase in production of ROS results in a decreased bioavailability of NO (59). Increased production of superoxide radicals results in the scavenging of $\mathrm{NO}$ and an increased production of peroxynitrite. Preliminary data from our laboratory show that, in male mice, LNAME had no effect on ANG II-induced hypertension. However, the depressor effect of tempol was inhibited by central co-administration of L-NAME, suggesting that NO may modulate the depressor effect of tempol in the development of ANG II-induced hypertension (49). 


\section{Conclusions}

Our studies have demonstrated that there are sex differences in ANG II-induced hypertension in conscious mice, and that sex hormones such as androgen and E2 as well as their central receptors modulate this form of ANG II-induced hypertension. Our studies have also indicated that the interactions among sex hormones and ROS/NO within the circumventricular organs significantly influence ANG II-induced hypertension. Thus, given the links between NO and ROS and the role of sex hormones and ANG II in neurohumoral activation, it can be hypothesized that sex hormones, ANG II, NO, and ROS work in concert to regulate autonomic function. Figure 7 illustrates the balance between ROS and NO which is suggested to be involved in activation of the $\mathrm{AT}_{1}$ receptor. Both E2 and testosterone are hypothesized to modulate the effects of $\mathrm{AT}_{1}$ receptor activation by modulating the ROS/NO balance. The interactions of these factors are likely to contribute to cardiovascular protection or impairment. Ongoing studies in our laboratory focus on this hypothesis and are exploring the related mechanisms.

\section{References}

1. Messerli FH, Garavaglia GE, Schmieder RE, Sundgaard-Riise K, Nunez BD, Amodeo C. Disparate cardiovascular findings in men and women with essential hypertension. Ann Intern Med 1987; 107: 158-161.

2. Stampfer MJ, Colditz GA, Willett WC, Manson JE, Rosner B, Speizer $\mathrm{FE}$, et al. Postmenopausal estrogen therapy and cardiovascular disease. Ten-year follow-up from the nurses' health study. $N$ Engl $J$ Med 1991; 325: 756-762.

3. Burt VL, Whelton P, Roccella EJ, Brown C, Cutler JA, Higgins M, et al. Prevalence of hypertension in the US adult population. Results from the Third National Health and Nutrition Examination Survey, 1988-1991. Hypertension 1995; 25: 305-313.

4. Staessen J, Fagard R, Lijnen P, Amery A. The influence of menopause on blood pressure. Arch Belg 1989; 47: 118-122.

5. Brosnihan KB, Li P, Ganten D, Ferrario CM. Estrogen protects transgenic hypertensive rats by shifting the vasoconstrictor-vasodilator balance of RAS. Am J Physiol 1997; 273: R1908-R1915.

6. Chen YF. Sexual dimorphism of hypertension. Curr Opin Nephrol Hypertens 1996; 5: 181-185.

7. Rowland NE, Fregly MJ. Role of gonadal hormones in hypertension in the Dahl salt-sensitive rat. Clin Exp Hypertens A 1992; 14: 367375.

8. Fink GD, Bruner CA, Mangiapane ML. Area postrema is critical for angiotensin-induced hypertension in rats. Hypertension 1987; 9: 355-361.

9. Matsukawa S, Reid IA. Role of the area postrema in the modulation of the baroreflex control of heart rate by angiotensin II. Circ Res 1990; 67: 1462-1473.

10. Chabrashvili T, Kitiyakara C, Blau J, Karber A, Aslam S, Welch WJ, et al. Effects of ANG II type 1 and 2 receptors on oxidative stress, renal NADPH oxidase, and SOD expression. Am J Physiol Regul Integr Comp Physiol 2003; 285: R117-R124.

11. Zimmerman MC, Lazartigues E, Lang JA, Sinnayah P, Ahmad IM, Spitz DR, et al. Superoxide mediates the actions of angiotensin II in the central nervous system. Circ Res 2002; 91: 1038-1045.

12. Strehlow K, Rotter S, Wassmann S, Adam O, Grohe C, Laufs K, et al. Modulation of antioxidant enzyme expression and function by estrogen. Circ Res 2003; 93: 170-177.

13. Gragasin FS, Xu Y, Arenas IA, Kainth N, Davidge ST. Estrogen reduces angiotensin II-induced nitric oxide synthase and $\mathrm{NAD}(\mathrm{P}) \mathrm{H}$ oxidase expression in endothelial cells. Arterioscler Thromb Vasc Biol 2003; 23: 38-44.

14. Hawk T, Zhang YQ, Rajakumar G, Day AL, Simpkins JW. Testosterone increases and estradiol decreases middle cerebral artery occlusion lesion size in male rats. Brain Res 1998; 796: 296-298.

15. Johnson AK, Gross PM. Sensory circumventricular organs and brain homeostatic pathways. FASEB J 1993; 7: 678-686.

16. Xue B, Gole H, Pamidimukkala J, Hay M. Role of the area postrema in angiotensin II modulation of baroreflex control of heart rate in conscious mice. Am J Physiol Heart Circ Physiol 2003; 284: H1003H1007.

17. Fink GD. Long-term sympatho-excitatory effect of angiotensin II: a mechanism of spontaneous and renovascular hypertension. Clin Exp Pharmacol Physiol 1997; 24: 91-95.

18. Hendel MD, Collister JP. Contribution of the subfornical organ to angiotensin Il-induced hypertension. Am J Physiol Heart Circ Physiol 2005; 288: H680-H685.

19. De Luca LA Jr, Sugawara AM, Menani JV. Brain versus peripheral angiotensin II receptors in hypovolaemia: behavioural and cardiovascular implications. Clin Exp Pharmacol Physiol 2000; 27: 437442.

20. Bealer SL. Anteroventral third ventricle periventricular tissue contributes to cardiac baroreflex responses. Clin Exp Pharmacol Physiol 2000; 27: 460-464.

21. Xue B, Pamidimukkala J, Hay M. Sex differences in the development of angiotensin II-induced hypertension in conscious mice. Am J Physiol Heart Circ Physiol 2005; 288: H2177-H2184.

22. Doursout MF, Chelly JE, Wouters $P$, Lawrence C, Liang YY, Buckley JP. Effect of gender in centrally induced angiotensin II hypertension in dogs. Hypertension 1990; 15: I-117-I-120.

23. Fischer M, Baessler A, Schunkert $\mathrm{H}$. Renin angiotensin system and gender differences in the cardiovascular system. Cardiovasc Res 2002; 53: 672-677.

24. Chen YF, Naftilan AJ, Oparil S. Androgen-dependent angiotensino- 
gen and renin messenger RNA expression in hypertensive rats. Hypertension 1992; 19: 456-463.

25. Lim YK, Retnam L, Bhagavath B, Sethi SK, bin Ali A, Lim SK. Gonadal effects on plasma ACE activity in mice. Atherosclerosis 2002; 160: 311-316.

26. Kisley LR, Sakai RR, Fluharty SJ. Estrogen decreases hypothalamic angiotensin II AT1 receptor binding and mRNA in the female rat. Brain Res 1999; 844: 34-42.

27. Mendelsohn ME, Karas RH. Molecular and cellular basis of cardiovascular gender differences. Science 2005; 308: 1583-1587.

28. Huang A, Kaley G. Gender-specific regulation of cardiovascular function: estrogen as key player. Microcirculation 2004; 11: 9-38.

29. Pare G, Krust A, Karas RH, Dupont S, Aronovitz M, Chambon P, et al. Estrogen receptor-alpha mediates the protective effects of estrogen against vascular injury. Circ Res 2002; 90: 1087-1092.

30. Zhu Y, Bian Z, Lu P, Karas RH, Bao L, Cox D, et al. Abnormal vascular function and hypertension in mice deficient in estrogen receptor beta. Science 2002; 295: 505-508.

31. Saleh MC, Connell BJ, Saleh TM. Autonomic and cardiovascular reflex responses to central estrogen injection in ovariectomized female rats. Brain Res 2000; 879: 105-114.

32. Saleh TM, Connell BJ. Centrally mediated effect of 17 beta-estradiol on parasympathetic tone in male rats. Am J Physiol 1999; 276: R474-R481.

33. Saleh TM, Connell BJ. 17beta-estradiol modulates baroreflex sensitivity and autonomic tone of female rats. J Auton Nerv Syst 2000; 80: 148-161.

34. Li Z, Hay M. 17-beta-estradiol modulation of area postrema potassium currents. J Neurophysiol 2000; 84: 1385-1391.

35. Pamidimukkala J, Hay M. 17beta-estradiol inhibits angiotensin II activation of area postrema neurons. Am J Physiol Heart Circ Physiol 2003; 285: H1515-H1520.

36. Xue B, Pamidimukkala J, Hay M. Role of estrogen receptor alpha in angiotensin II-induced hypertension in conscious female mice. FASEB J 2005; 19: A617 (Abstract).

37. Xue B, Johnson RF, Beltz T, Johnson AK, Hay M. Central estrogen attenuates ANG II-induced hypertension in ovariectomized female mice. Experimental Biology 2006. April 1-5; San Francisco. 2006. p 37. Late Breaking Abstract 164.

38. Reckelhoff JF. Gender differences in the regulation of blood pressure. Hypertension 2001; 37: 1199-1208.

39. Harshfield GA, Alpert BS, Pulliam DA, Somes GW, Wilson DK. Ambulatory blood pressure recordings in children and adolescents. Pediatrics 1994; 94: 180-184.

40. Reckelhoff JF, Zhang H, Srivastava K. Gender differences in development of hypertension in spontaneously hypertensive rats: role of the renin-angiotensin system. Hypertension 2000; 35: 480-483.

41. Ouchi Y, Share L, Crofton JT, litake K, Brooks DP. Sex difference in the development of deoxycorticosterone-salt hypertension in the rat. Hypertension 1987; 9: 172-177.

42. Reckelhoff JF, Zhang H, Srivastava K, Granger JP. Gender differences in hypertension in spontaneously hypertensive rats: role of androgens and androgen receptor. Hypertension 1999; 34: 920-923.

43. Dubey RK, Oparil S, Imthurn B, Jackson EK. Sex hormones and hypertension. Cardiovasc Res 2002; 53: 688-708.

44. Xue B, Skala K, Pamidimukkala J, Hay M. Androgens modulate angiotensin II-induced hypertension in conscious male mice. FASEB J 2004; 18: A649 (Abstract).

45. Mates JM, Perez-Gomez C, Nunez de Castro I. Antioxidant enzymes and human diseases. Clin Biochem 1999; 32: 595-603.

46. Zimmerman MC, Lazartigues E, Sharma RV, Davisson RL. Hypertension caused by angiotensin II infusion involves increased superoxide production in the central nervous system. Circ Res 2004; 95: 210-216.

47. Zimmerman MC, Davisson RL. Redox signaling in central neural regulation of cardiovascular function. Prog Biophys Mol Biol 2004; 84: 125-149.

48. Pamidimukkala J, Xue B, Hay M. Role of ROS in angiotensin IIactivation of area postrema (AP) neurons and systemic hypertension. Experimental Biology 2004. April 17-21; Washington. 2004. p A103. Late Breaking Abstract 501.

49. Xue B, Zhao Y, Beltz T, Johnson RF, Johnson AK, Hay M. The effects of L-NAME and tempol in Ang II induced hypertension in male mice. FASEB J 2006; 20: A1207 (Abstract).

50. Zhao Y, Pamidimukkala J, Hay M. Angiotensin II evoked increases in reactive oxygen species in subfornical organ neurons in the living brain slice. FASEB J 2005; 19: A1291 (Abstract).

51. Vincent SR, Kimura $\mathrm{H}$. Histochemical mapping of nitric oxide synthase in the rat brain. Neuroscience 1992; 46: 755-784.

52. Patel KP, Li YF, Hirooka Y. Role of nitric oxide in central sympathetic outflow. Exp Biol Med 2001; 226: 814-824.

53. Hodgin JB, Knowles JW, Kim HS, Smithies O, Maeda N. Interactions between endothelial nitric oxide synthase and sex hormones in vascular protection in mice. J Clin Invest 2002; 109: 541-548.

54. Rachman IM, Unnerstall JR, Pfaff DW, Cohen RS. Regulation of neuronal nitric oxide synthase mRNA in lordosis-relevant neurons of the ventromedial hypothalamus following short-term estrogen treatment. Brain Res Mol Brain Res 1998; 59: 105-108.

55. Ceccatelli S, Grandison L, Scott RE, Pfaff DW, Kow LM. Estradiol regulation of nitric oxide synthase mRNAs in rat hypothalamus. Neuroendocrinology 1996; 64: 357-363.

56. Singh R, Pervin S, Shryne J, Gorski R, Chaudhuri G. Castration increases and androgens decrease nitric oxide synthase activity in the brain: physiologic implications. Proc Natl Acad Sci U S A 2000; 97: 3672-3677.

57. Xue B, Skala K, Pamidimukkala J, Hay M. Protective effect of central nitric oxide (NO) in angiotensin II-induced hypertension in conscious female mice. FASEB J 2005; 19: A617 (Abstract).

58. Wang YR, Yen CH, Sun YF, Laun YT. Gender-dependent response in blood pressure changes following the inhibition of nitric oxide synthase. Chin J Physiol 2003; 46: 91-94.

59. Darley-Usmar VM, McAndrew J, Patel R, Moellering D, Lincoln TM, Jo $\mathrm{H}$, et al. Nitric oxide, free radicals and cell signalling in cardiovascular disease. Biochem Soc Trans 1997; 25: 925-929. 